\title{
Gastronomy tourism potential of Sinop (Turkey) destination
}

\author{
Alpay Tiril $^{1}$, Demet Kocatepe ${ }^{2}$, Mehmet Sedat Ipar ${ }^{3}$ \\ 1 - Sinop University, School of Tourism and Hotel Management, Sinop, Turkey \\ 2 - Sinop University, Fisheries Faculty, Sinop, Turkey \\ 3 - Sinop University, Vocational School, Dept. of Tourism and Hotel \\ Management, Sinop, Turkey
}

Keywords:

Gastronomy

Tourism

Black Sea

Foods

Culture

Cuisine

Sinop

Article history:

Received 18.05.2017

Received in revised

form 30.06.2017

Accepted 05.09.2017

Corresponding

author:

Demet Kocatepe

E-mail:

demetkocatepe@

hotmail.com
DOI: $10.24263 / 2310-$

1008-2017-5-1-17

\section{Abstract}

Introduction. The investigation of traditional food heritage of Sinop and reuse of it as a touristic product in tourism market is aimed in this article.

Materials and methods. In this study, the kitchen literatures related to Sinop and personal experiences from people living in the region had been complied. Made an inference about the current and future gastronomy tourism situation of Sinop by the identifying with oral interviews technique.

Results and discussion. Tourism is a multidimensional phenomenon, interested in all natural and cultural entities and cases. In this context, nourishment as very important components of tourism sector besides some of the tourists travel due to gastronomic experiences. Sinop province is little-known as gastronomic tourism in Turkey. Sinop City is on the Peninsula of the northern part of the province. The city derived from Iron Age and colonized by Miletus in $8^{\text {th }}$ century before as a part of Greek Culture.

Sinop has been a little and undevelopment fishing town during the republic period. That's why, the town wasn't impressed by the effects of industrialization. Besides the natural beauty of Sinop it is also reflected in the kitchen with the accumulation of the effects of different civilization. In Sinop cuisine mainly fish dishes is located in the kitchen culture due to the Sinop is peninsula, are also incorporates many flavors previously mentioned. It is being referred to the touristic point of the sea and the natural beauty of Sinop, unable to so much prominence local cuisine. With the caught season staring in 15 September, tourists from near the city of Sinop to eat fish are the most important element of gastronomic tourism. Traditional foods are important part of cultural heritage of Sinop province, however, today their presentation / announcements are not done sufficiently.

Conclusion. It can be suggested to destination planners to use local cuisines as a part of tourism marketing. Particularly with the growing tourism potential of Sinop region, introduction of regional cuisine and related activities should be accelerated. 


\section{Introduction}

The whole tourism activities require any kind of attractiveness in destinations. To have more attractiveness is the first necessity to gain more tourist for all touristic destinations. Tourists are interested in different spaces and activities. But all tourists who travels for anything, need food and beverage in every destination in every time and case. That's why offering food and beverage is very important part of tourism sector. Moreover, cuisines of touristic destinations can be attractiveness for some tourists by itself. If the visiting case of except cuisines, tourist mostly taste native foods and beverages. So, cuisines of destinations are interested in all tourists.

Before as the authors stated [1], people are increasingly interested in exploring local cuisines or tasting famous chefs' meals, unique destinations with different destinations and local cuisine. . While the concept of travel for food has gained a new meaning with the beginning of the spice trade, voyagers still carry with dried vegetables for their diets [1]. In tourism industry of Turkey food and beverage form the largest portion of revenues. Food and beverage spending is more than hospitality and the share of total income is between 20 25 percent. A total of incoming of Turkey from tourism industry at 2004 was about 17 billion dollars which 3.1 billion of them was related to food and beverage. After 11 years this amounts have been doubled. In other words, total revenue reached to 34.3 billion which 6 billion 523 million dollar of them are for food and beverage. By the end of 2014, the expenditure done by tourists for food are 19-20 percent of total expenditure. This indicates that $1 / 5$ of incomings from tourism are concern to eating and drinking. According to the survey done by TUIK [2] in Turkey in 2014, 157 dollar in average was spent on food and beverage by each tourist [2].

According to the report of TURSAB Gastronomic Tourism [3]; "88.2 percent of tourists in the world says that "the food is a very important factor when they choose destination. Food related events make the major part of gastronomic tourism activities. About 80 percent of the world companies operating in this field, usually state their food products for food events. In the United States 17.879 people are working in various tourism community such as restaurant, cooking schools, travel agencies, hotels and other related fields. In this ranking system Turkey with 94 various communities stands in $23^{\text {rd }}$ place". Tourism depends on two main bases. They contain all kinds of touristic attractiveness. They are natural and cultural issues. Food and beverage concepts are the extension both of them. Disperse of the traditional foods in the world is mostly related geographical factors [4]. Those factors derived nature also cultural structure derives nature. But cultural issues are also related with interactions of another cultures. Those kind of cultural transfers is also seen in nourishment. Immigrations effect the disperse of food and beverage in the space.

The nutritional needs within its physical needs are one of the essential requriements of tourism varieties all over the world. Ardabili et al. [5] reported as food impresses other aspects such as travel agencies' culinary program, final price of hotels, culture assimilation and many other components.

Moreever, diversity of traditional foods are very important component of culturel tourism. To supply of traditional cuisine to tourism market also ensure to sustain traditional foods. Otherwise, those kind of foods will not kept by next generations and be forgotten. It could be said another side of traditional foods in tourism for the side of producing them from the field. In this approach is related with agrotourism as a part of ecotourism. Ecotourism is not only a nature sensibility recreation model but know and keep natural and traditional process [6]. It also contains agricultural and basic homemade foods (Figure 1). It can be accepted first step of traditional foods using in tourism market. Process of producing 


\section{- Economics and Management -}

traditional foods is not familiar to youth members of the modern societies. Some of them, mostly educated and sensible for the natural and cultural heritage is volunteer to participate that kind of activities as a tourist. Turkey can offer many alternatives for them. Those activities starts from harvest on fields or wine yards to participate all process of producing foods and the eat them. Tourism market in Turkey is not good enough in this compartment.

For the foods; "traditional" means proven usage on the Community market for a time period showing transmission between generations; this time period should be the one generally ascribed to one human generation, at least 25 years [7]. In 2007, European Commission [8] gave the following definition of "traditional foods": traditional food is food with a specific feature or features that distinguishes it clearly from other similar foods in terms of the use of "traditional ingredients", "traditional composition" and "traditional type of production and/or processing methods".

To participate the ecotourist to production of homemade traditional foods in rural settlements and farms is one side of using of traditional foods in tourism. The other side is using them in touristic kitchens.

Industrialization radically changed to preparation of foods [9]. Traditional foods are against to negative results of modern nourishment. All cultural components are become global by modernism. One of the result of this globalization is lacking of traditional foods. To use them in tourism results to be known in the future.

Another importance using traditional agricultural production, homemade food production and offer traditional foods in touristic management are creating economic value both tourism sector and traditional producers. According to Demirer [10], consumptors can pay more 18 percent for regional agricultural productions. Traditional agricultural and food production is mostly sustained for local agricultural, villages, hunters, cook etc. To use traditional productions in tourism sector is developed those people of rural societies. This part of the society is mostly poorer the other part of the society. To use their product is both sustain traditional cultural components and keep them in their homeland. So it is the barrier of immigration which causes social disasters. Among the reasons why European consumers prefer traditional foods are chosen weight control, convenience, familiarity, healthiness and natural content [11].

\section{Methodology}

In this study, the kitchen studies related to Sinop and personal experiences from people living in the region had been complied. The scope is to discuss the role of traditional food and beverage in Sinop, Turkey. The following research questions were adopted from Okech [12] and used for this reason.

Sinop province is little-known as gastronomic tourism in Turkey. The purpose of this research, to make an inference about the current and future gastronomy tourism situation of Sinop by the identifying with oral interviews technique. In according with the basic purpose, it will try to reveal the status of gastronomic tourism in the province.

\section{Research questions}

- What are the touristic supply of traditional foods in Sinop?

- Why is culinary tourism important for Sinop?

- What is the role of gastronomy tourism in Sinop cultural heritage and on economy? 


\section{Study area}

Sinop is one of the small provinces in Turkey. It is on the northern part of Turkey. Northern board of the province is nearly $175 \mathrm{~km}$ coast next to Black Sea. Kastamonu Province is the western, Çankırı Province is the southern and Samsun Province is the eastern and southeastern neighbors of Sinop Province. The area of the province is 5862 kilometer square, 0.8 percent of Turkey [13]. The topography of the province is mostly rough, nearly 75 percent consist of mountains [14]. The Northern Anatolia mountain line which is on the west-east direction divides the province not only physical but cultural conditions. The northern part of the mountain range is by the effect of sea, both climatic, floristic and cultural structure. The southern part of the mountain range has terresterial landscapes and culture. There is no big river in the province. The important river of the province is Gökırmak, which is the branch of the longest river of Turkey, Kizilırmak. Ayancik Stream, Karasu Stream and Kabalı Stream are some important rivers of the province.

The province has loosen population due to employment problems. The population of the province is 204.133 in 2015 [2]. This population has ethnic diversity which influences the kitchen diversity of the province. The center of the province is Sinop city, also the biggest city in the province. Sinop City is on the Peninsula of the northern part of the province. The city derived from Iron Age and colonized by Miletus in $8^{\text {th }}$ century before as a part of Greek Culture. Miletus rebuilt the castle and Sinop became an important harbor city. The importance of the city comes it has two harbors one is on the north the other is on the south. All coasts of the northern part or Turkey sees the north. But Sinop is the only one city in Black Sea coast of Turkey sees to south. Also Sinop is the only one natural harbor on Black Sea costs of Turkey [16].

Turkish army first conquered Sinop in eleventh century. Seljukian Turks had the town again in 1214 and they built the first Turkish shipyard of Seljukian State in Anatolia. Sinop had become an important shipyard center of Turkish navy in Seljukian and Ottoman Period. Sinop also had been an important harbor town until Russian attack from the sea. Russian navy bombed fired the town in 1853. After the Crimean war that happened in 1853-56, Paris Convention signed in 1856. Sinop military shipyard was closed according to convention. It collapsed the economy of Sinop.

Russia exiled Muslim Caucasian people in the second half of nineteenth century. Most of the Muslim Caucasian people immigrated to Ottoman also Sinop. They brought their cultures. That's why, Caucasian cuisine is very common in Sinop. Sinop has been a little and undevelopment fishing town during the republic period. That's why, the town wasn't impressed by the effects of industrialization.

\section{Results and discussion}

\section{Potential of Touristic Supply of Traditional Foods in Sinop}

Sinop kitchen has a great diversity due to diversity of both natural conditions and cultural structure. Long coasts, abundant plains, wetlands, plateaus, forests, orchards etc. are the one source of this diversity. Sinop province has both coastal ecosystems, mountain ecosystems and terrestrial ecosystems. This diversity ensures to product different agricultural yields. Sinop is also a developed fishing center. Sea foods are another richness of the province. Plant and animal diversity gives many materials for kitchen. Those material 


\section{- Economics and Management -}

richness was supported by cultural diversity. Lots of immigrants have been come from the other coastal cities of Northern Anatolia, Caucassia and Crimea. Native Sinopians, other Black Sea people of Northern Anatolia, different Caucassian nations and Crimeans mixed in coastal Sinop. They all added their traditional foods to Sinop kitchen. On the other hand, on the southern part of the mountains culture is different from the coastal culture. This terrestrial culture in inner part of Sinop had created own kitchen which give richness to Sinop kitchen. Both natural and cultural diversity has shaped Sinop kitchen.

Turkey is a peninsula with its three sides surrounded by the sea. People who are living in the north part of this country mostly occupy fishing to livelihood. By starting the fishing season in 15th September, number of domestic tourists and subsequently fish consumption shows an increase. One of the most important food served in provinces' restaurants for domestic or foreign tourists is "Manti" which natives call it "Kulak Hamuru" (Figure 1a). Sinop's Nokul (Figure 1b) presented with minced meat, potatoes, walnuts, walnut/raisin and spinach is another production of this region that attract the attention of tourists. Sinop salted fish (Figure 1c), Sinop chestnuts, Sinop solid sour apple molasses (Figure 1d), corn Keshkek, fresh/dried wild mushroom species (Figure 1 e, f), are among delicacies purchased by native and foreign tourists. Dried/frozen "Kulak hamuru" are available in the stated restaurants, various types of "nokul" are sold in confectionaries and mobile vendors, fishmongers sell different types of salted fishes in plastic jars, also Sinop chestnuts, don molasses, corn Keshkek, fresh/dried wild mushroom species are available in the village markets.

Seafood consist important part of Sinop kitchen. Black Sea has a great fish diversity. These fishes and other seafood has used to food since ancient era. Turan et al. [17] and Kocatepe and Turan [17] searched some of them. Bonito, anchovy, whiting, horse-mackerel etc. are some important fishes of Sinop. Sinop is covered on three sides, and the livelihood source of majority of Sinop people is fishing. It is said that the most and the best fresh seafood consumed in Sinop. It is inevitable that, the diversity of fish dishes are more in the city earn their live hood from the sea [19]. The usage of fish and especially anchovy are quite a lot in season and out of season in Sinop kitchen. They were cooked in different styles. Anchovy is the most known and consumed fish in Black Sea coast of Turkey. In Turkish black sea culture, anchovy is not a fish, just an anchovy. Sinop is the most important center of anchovy fishing in Turkey. Turkish people on Black Sea coast have been using anchovy in every kind of food as fries, grilled, pickled, with vegetable, with rice etc. Anchovy rice is very preferred food for Black Sea Coast in anchovy season. But it is nearly impossible to find this unique taste in touristic management (Figure 2). 


\section{- Economics and Management -}
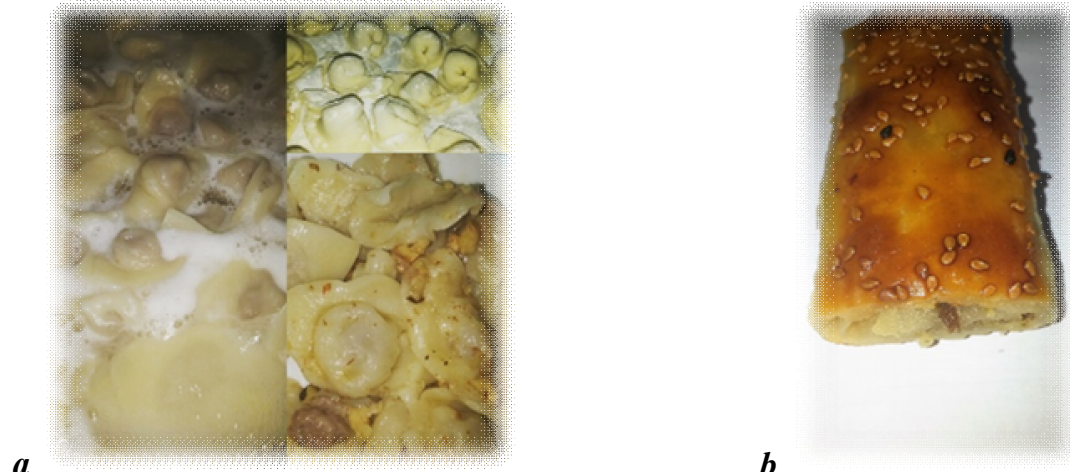

$c$
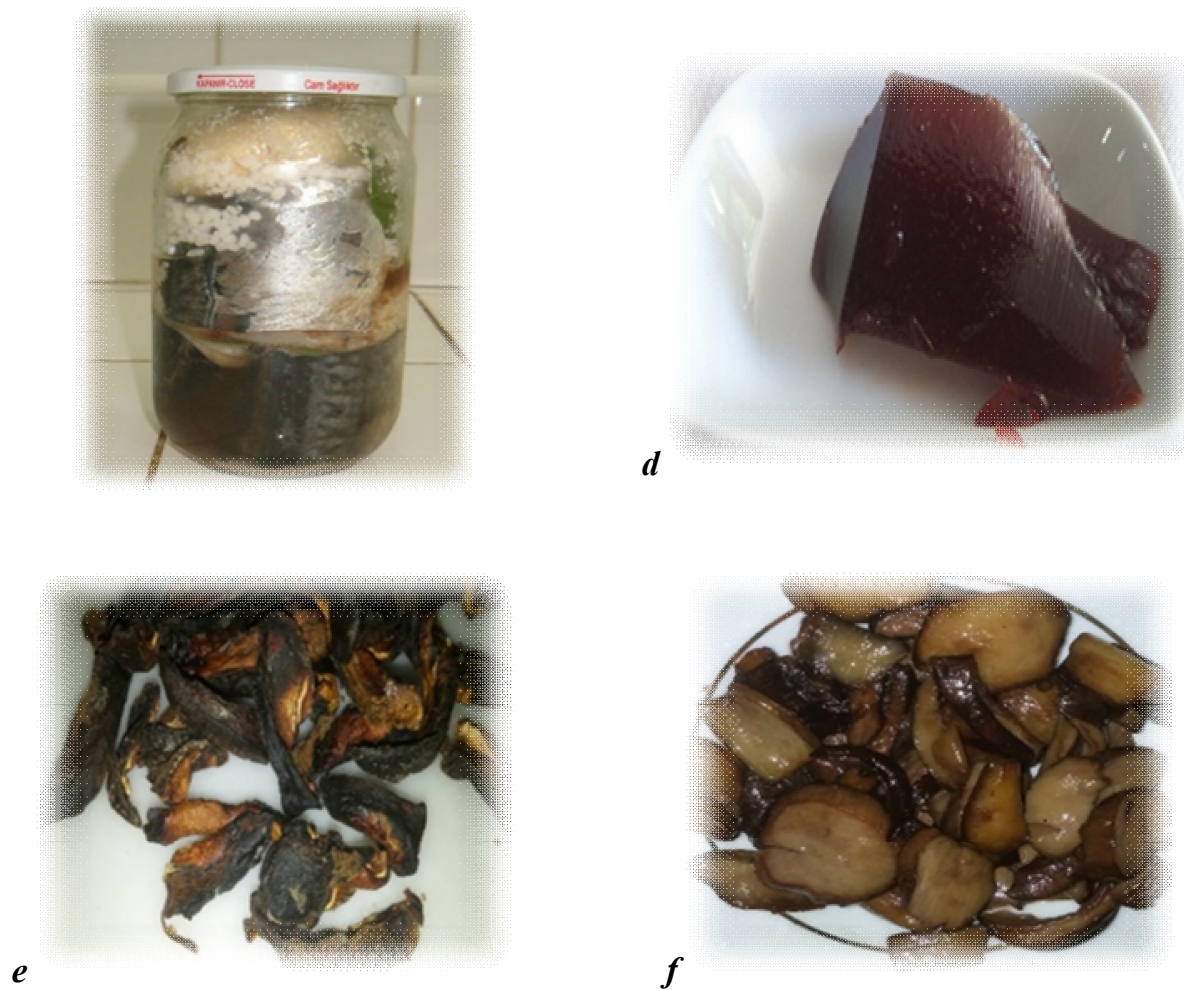

Figure 1. $a$ - Kulak Hamuru; $b$ - Nokul, $c$-Salted bonito; $d$-Apple Molasses; $e$-Dried mushroom (Boletus edulis) fried mushroom (Boletus edulis) (Photos: D. Kocatepe). 

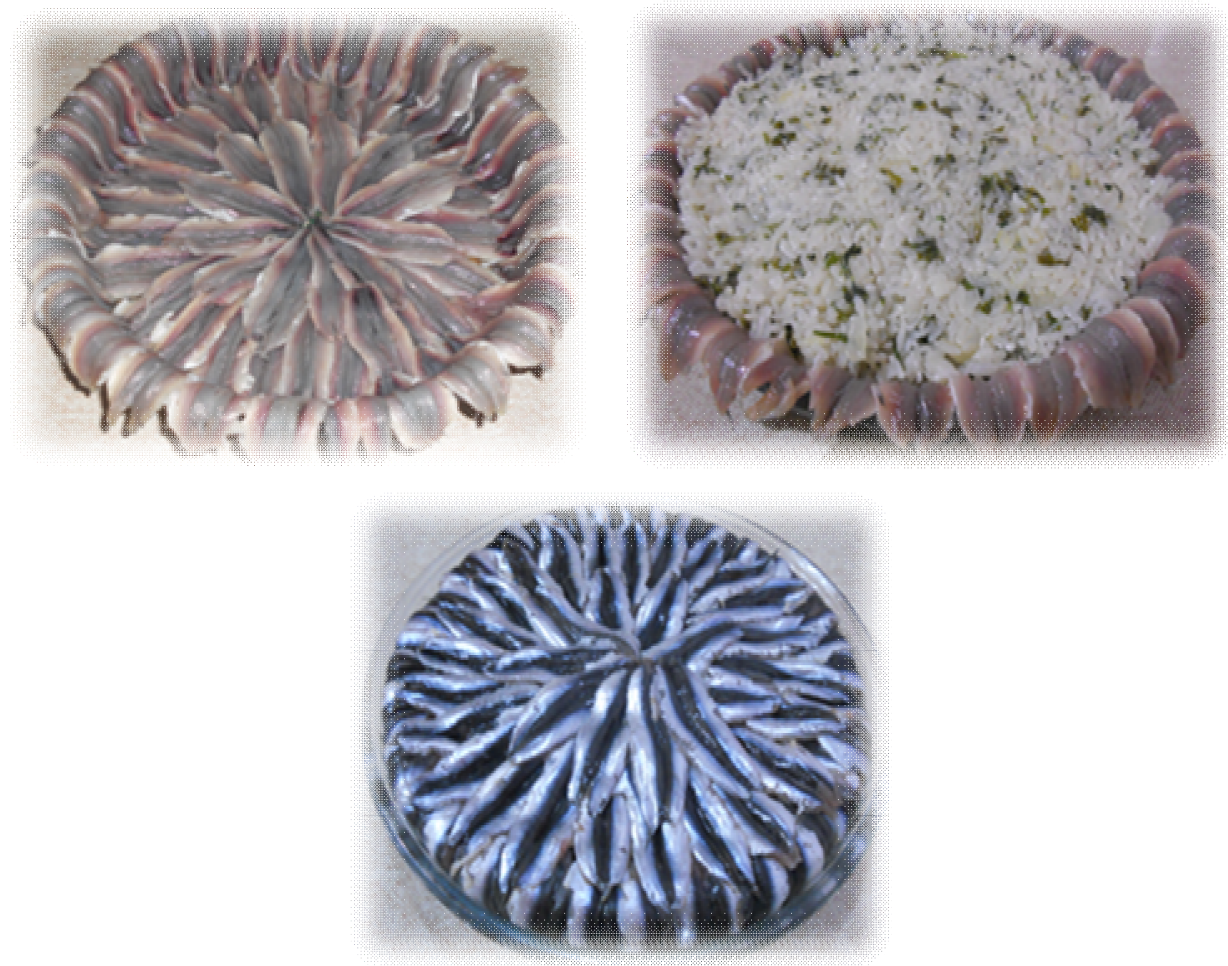

Figure 2. Anchovy rice (Photos: A. Turll).

\section{Why is culinary tourism important for Sinop?}

Nowadays, many countries develop their interests and plans to gastronomic tourism. Protection of cultural properties in the ever-evolving world is of great importance for nations. Eating habits are gradually changing with globalization and are going to be unhealthy, for instance, rapid consumption patterns are increasing. All the generations are affected by rapid consumption culture brought by fast food. Being host for many civilizations, Sinop is a city that inspired with different cultures in its cuisine. Traditional delicacies made by native people during centuries though lost its value by passing the days, rural areas and restaurants with local cuisine maintain its vitality. Uncovering these almost forgotten values will be positive for both natives and visitors. Thus, as well as many other countries some programs such as competitions, festivals, etc. can be arranged in this region to introduce the local tastes.

For example, in Taiwan in 2010 the Council for Economic Planning and Development launched the "Gourmet Taiwan International Action Program"- an Action Plan for the internationalization of Taiwanese cuisine. The objectives of this program were to boost the global competitiveness of Taiwanese restaurant industry, to flourish the Taiwan tourism and ultimately to increase the tourism destination attraction [20]. The world famous International Gourmet Festival in Portugal in 2013, $10^{\text {th }}$ Malaysia International Gourmet 
Festival in 2010 were organized. These festivals, celebrations or contests are spectacular, so, gastronomic tourists increase in these dates. To be host for different gastronomic delicacies beside to natural and cultural beauties of Sinop province, cause to increasing its attractiveness for tourists.

It's possible to eat fresh Black Sea fishes in one of ship-restaurants at the seaside, tirit or kulak hamuru in historical madrasa (theological school) and also it's common to enjoy smell of Sinop nokul in tea gardens of Sinop. Sinop local delicacies are sold from these businesses provide the livelihood for many families. To increase the stability of both the local flavor in mind as well as cultural heritage stands out.

Traditional foods are important part of cultural heritage of Sinop province, however, today their presentation / announcements are not done sufficiently. Additionally, the number of brochures, books and publications concern to traditional foods and meals of Sinop is quite low. Among these studies are Karataş et al. [21], Turan et al. [17-19], Kocatepe and Turan $[22,23]$.

\section{What is the role of gastronomy tourism in Sinop cultural heritage and on economy?}

There are many tourists who travel for reasons of seeking culinary experience. Tourism activity related to food has been labeled such as food tourism, gourmet tourism, cuisine tourism, culinary tourism, or gastronomy tourism. This distinction between food tourism and food as a part of the travel experience is evident in research that has classified tourists based on the importance of food in the overall trip decision making process [24, 25]. Many researchers revealed that tourists spend almost 40 percent or one-third of their budget on food when travelling $[26,27]$

Hall and Mitchell [28] defined food tourism as, "visitation to primary and secondary food producers, food festivals, restaurants and specific locations for which food and tasting and/or experiencing the attributes of a specialist food production region are the primary motivating factors for travel".

Food is one of our basic needs, so it is not surprising that it is also one of the most widespread markets of identity. Given the strong relationship between food and identity, we understand why food came become an important marketing tool in tourism promotion and gastronomy tourism, specifically, an effective tool for regional development. One of the basic reasons for this phenomenon is the strong relationship between certain localities and special types of food. Food can also be used as a mean for guiding tourists around regions or countries. The close association of gastronomy to local, regional and national identity is apparently threatened by the process of globalization. However, lately it is believed recently by many that "Local has become a treasure": Especially in rural destinations, we can seek for comparative and competitive advantages in their diversified gastronomy traditions [29].

Besides the natural beauty of Sinop it is also reflected in the kitchen with the accumulation of the effects of different civilization. In Sinop cuisine mainly fish dishes is located in the kitchen culture due to the Sinop peninsula, are also incorporates many flavors previously mentioned. It is being referred to the touristic point of the sea and the natural beauty of Sinop, unable to so much prominence local cuisine. With the caught season staring in 15 September, tourists from near the city of Sinop to eat fish are the most important element of gastronomic tourism.

Fresh seafood in beach resorts, traditional cookery, the famous restaurants in expensive hotels, on the cruise liners or in the major commercial centers all and all are built for this 


\section{- Economics and Management -}

purpose. In fact, all the countries and even cities expand their unique culinary attractions to engage more travelers. Food Tourists, compared to other tourist groups, have been the most faithful group to destination. In their decision making for selecting the destination of travel, local meals perform a crucial role [25].

Sinop is the "happiest city" in Turkey according to the TUIK report about "Turkey 2013, Provincial-level life satisfaction". It is also the second province in the same year was the highest satisfaction by rendering public security services [13]. These factors make it attractive for Sinop tourism.

\section{Conclusion}

In this paper, local kitchens and traditional foods were evaluated by tourism sector in Sinop case. It is necessity both to sustain traditional cultures and to increase market rate of tourism. Tourism professionals have to work on this concept more. One of the main and important way of developing tourism market is creating attractiveness which are new and interested in more people in the market. Food and beverage are not only interested in tourists but all people. Due to they are the most important part of main life activities of all people, also a pleasure and desiring elements of most of the tourists. So, as gastronomy tourism is the specific one in tourism species, and it is the component of all tourism species and activities. This reality is an important argument to destination which have extra ordinary cuisine. It was suggested to destination planners to use local cuisines as a part of tourism marketing. Particularly with the growing tourism potential of Sinop region, introduction of regional cuisine and related activities should be accelerated. For this purpose, local product promotion fairs, workshops, competitions, etc. should be organized with special supports. It will be ensure both developing tourism and conserving local cultures and tastes.

\section{References}

1. Shenoy S.S. (2005), Food Tourism and the Culinary Tourist. Graduate School of Clemson University, Doctor of Philosophy Thesis in Parks, Recreation and Tourism Management, Clemson, USA.

2. TUIK (2015), Turkey 2002-2016- Tourism Income by Type of Expenditure. Turkish Statistical Institute, http://www.tuik.gov.tr/PreTablo.do?alt_id=1072 (in Turkish).

3. TURSAB (2014), Gastronomy Tourism Report, Association of Turkish Travel Agencies, İstanbul, Turkey.

4. Doğu A.F. (2009), Geography of Foods. $2^{\text {nd }}$ Traditional Foods Symposium, May 2729, 2009, Van, Turkey, Proceedings Book, pp. 1-4 (in Turkish).

5. Ardabili F.S., Rasouli E., Daryani S.M., Molaie M. and Sharegi B. (2011), The Role of Food and Culinary Condition in Tourism Industry. Middle-East Journal of Scientific Research. 9(6), pp. 826-833.

6. Tiril A. (2007), Ecotourism as a Tool for the Reorganize of Man-Nature Relations. Çeşme National Tourism Symposium, November 21-23, 2007, Çeşme, İzmir, Turkey, Proceedings Book, pp. 603-609 (in Turkish).

7. European Commission (2006), Council Regulation (EC) No 509/2006 of 20 March 2006 on Agricultural Products and Foodstuffs as Traditional Specialties Guaranteed. Official Journal of the European Union L 93/1. 


\section{_- Economics and Management -}

8. European Commission (2007), European Research on Traditional Foods, Community Research. Luxembourg: Official Publication of the European Communities.

9. Pilcher J.M. (2006), Food in World History. Routledge, New York, USA.

10. Demirer H.R. and Mencet N. (2009), The Contribution of Traditional Yields to Economic Development. $2^{\text {nd }}$ Traditional Foods Symposium, May 27-29, 2009, Van, Turkey, Proceedings Book, pp. 236-240 (in Turkish).

11. Pieniak Z., Verbeke W., Vanhonacker F., Guerrero L. and Hersleth M. (2009), Association Between Traditional Food Consumption and Motives for Food Choice in Six European Countries. Appetite, 53, pp. 101-108.

12. Okech R. N. (2014) Promoting the Spa Tourism Industry: Focus on Coastal Resorts in Kenya. Athens Journal of Tourism, 1(1), pp. 67-68.

13. TUIK (2014), Turkey 2013-Provincial Level Life Satisfaction. Turkish Statistical Institute, http://www.tuik.gov.tr/PreHaberBultenleri.do?id=18507 (in Turkish).

14. Tirll A. (2016), Rural Landscape Readings by the Context of Folk Culture. $1^{\text {st }}$ National Ankara University Landscape Architecture Congress, October 15-17, 2015, Ankara, Turkey, Proceedings Book, pp. 102-115 (in Turkish).

15. Anonymous (2016), http://www.maplandia.com/turkey/sinop/sinop/ (05.01.2016).

16. Trrll A. (2010), Sinop in Republic Era (1923-1950). Dokuz Eylul University, Institute of Social Scineces, Department of History, Unpublished Master Thesis, Izmir, Turkey (In Turkish).

17. Turan H., Kaya Y. and Kocatepe D. (2009), A Traditional Food of Us: Dry-Salted Bonito. $2^{\text {nd }}$ Traditional Foods Symposium, May 27-29, 2009, Van, Turkey, Proceedings Book, pp. 111-114 (in Turkish).

18. Turan H., Kocatepe D. and Altan C.O. (2012), Mullet Caviar. $3^{\text {rd }}$ Traditional Foods Symposium, May 10-12, 2012, Konya, Turkey, pp. 229-230 (In Turkish).

19. Turan H., Altan C.O., Kocatepe D. and Ceylan A. (2013), The Quality of Lakerda Made With Different Technics in Sinop Region. $2^{\text {nd }}$ International Symposium on Traditional Foods from Adriatic to Caucasus, October 24-26, 2013, Struga, Macedonia, Abstract Book, p. 324.

20. Wu W.W., Lan L.W. and Lee Y.T. (2011), Exploring Crucial Features of Kansei Hybrid Cuisine Design: Rough Set Approach. International Journal of Kansei Information, 2, pp. 157-66.

21. Karataş G., Genç S. and Aydemir F. (2012), Ceziretü'l-Uşşak'tan LezzetlerUnutulmaya Yüz Tutmuş Sinop Yemekleri. Sinop Kız Teknik ve Meslek Lisesi Kültür Yayınları, Yayın No:1, Sinop, Turkey.

22. Kocatepe D. and Turan H. (2012), Traditional Bonito Dishes in Sinop. $3^{\text {rd }}$ Traditional Foods Symposium, May 10-12, 2012, Konya, Turkey, Proceedings Book, pp. 167-168 (in Turkish).

23. Kocatepe D. and Turan H. (2013), The Usage of Anchovy in Sinop Kitchen. The $2^{\text {nd }}$ International Symposium on Traditional Foods from Adriatic to Caucasus, October 24-26, 2013, Struga, Macedonia, Abstract Book, p. 286.

24. Okumus B., Okumus F. and McKercher B. (2007), Incorporating Local and International Cuisines in the Marketing of Tourism Destinations: The Cases of Hong Kong and Turkey. Tourism Management, 28, pp. 253-261.

25. Ab Karim S. and Chi C.G. (2010), Culinary Tourism as a Destination Attraction: An Empirical Examination of Destinations' Food Image. Journal of Hospitality Marketing and Management, 19, pp. 531-555. 


\section{Economics and Management -}

26. Telfer D.J. and Wall G. (2000), Strengthening Backward Economic Linkages: Local Food Purchaising by Three Indonesian Hotels, Tourism Geographies, 2(4), pp. 421447.

27. Mahrus M. (2014), Promoting Culinary Heritage for Indonesia Tourism Development, ISCONTOUR 2014-Tourism Research Perspectives (Ed: R. Eggerand and C. Maurer), pp. 57-67.

28. Hall M., and Mitchell R. (2001), Wine and Food Tourism. In Special Interest Tourism (Eds: N. Douglas and R. Derrett), Australia: John Wiley, pp. 307-325.

29. Karagiannis D. and Metaxas T. (2015), Culinary Tourism In Greece: Can the Past Define the Future? A Comparative Analysis by Using 10 Case Studies. Munich Personal RePEch Archive, https://mpra.ub.uni-muenchen.de/66846/ 